\title{
Tantangan tata Kelola Kebijakan Perubahan Iklim di Indonesia (Studi Kasus: Komparasi Antara Penerapan Desentralisasi dan MuLti-LeVEL Governance)
}

\author{
Rifka Sibarani ${ }^{1}$
}

\begin{abstract}
Abstrak
Intergovernmental Panel of Climate Change (IPCC) menyarankan untuk menggunakan pendekatan multi-level governance (MLG) untuk mengimplementasi kebijakan perubahan iklim, seperti yang telah diterapkan di Uni Eropa. Indonesia adalah salah satu negara yang masih menggunakan pendekatan desentralisasi dalam implementasi kebijakan perubahan iklim dan kondisi ini memiliki tantangan tersendiri.

Artikel ini menggunakan pendekatan studi pustaka dan berfokus pada dokumen pemerintah, laporan dari media massa dan studi akademis untuk mengeksplorasi tantangan tata kelola kebijakan perubahan iklim di Indonesia dalam perspektif multi-level governance (MLG) di Indonesia, dengan melihat implementasi RAD-GRK di Sumatera Utara. Temuan dalam studi ini menunjukkan bahwa desentralisasi merupakan tantangan kebijakan perubahan iklim di Indonesia, yang mana manghasilkan permasalahan, antara lain, koordinasi yang buruk di instansi pemerintah dan tidak ada keharusan hukum bagi pemerintah daerah dan kota untuk memberikan tingkat emisi mereka.
\end{abstract}

Kata kunci: multi-level governance, climate change policy, decentralisation

1 Penulis adalah pengajar di Universitas Atma Jaya Yogyakarta 


\section{Abstract}

The Intergovernmental Panel of Climate Change (IPCC) recommends using the MultiLevel Governance (MLG) approach to implementing climate change policies, as applied in the EU. Indonesia is one of the countries that still uses decentralization approach in the implementation of climate change policy and this condition has its own challenges.

This article uses a literature approach and focuses on government documents, media reports and academic studies to explore the challenges of climate change governance in Indonesia by comparing the MLG and the decentralisation approaches and looking the implementation of RAD-GRK in North Sumatera, Indoensia The findings in this study indicate that decentralisation is a challenge to climate change policy in Indonesia, which creates problems, among others, poor coordination in government agencies and there is no legal requirement for local and municipal governments to provide their emission levels.

Keywords: multi-level governance, climate change policy, decentralization

\section{Pendahuluan}

Dalam studi kebijakan publik dan hubungan internasional, kebijakan perubahan iklim merupakan isu yang pelik. Dikarenakan lingkup permasalahan kebijakan yang kompleks, beberapa studi menyebut isu kebijakan perubahan iklim sebagai "the super wicked problem". ${ }^{23}$ Kompleksitas permasalahan kebijakan perubahan iklim serta skala dari kompleksitas penanganan dampak dari perubahan iklim tersebut membuat perubahan iklim sebagai krisis global yang sangat penting di abad ini bagi negara maju dan berkembang, ${ }^{4}$ termasuk Indonesia.

Indonesia merupakan salah satu pihak yang meratifikasi piagam United Nations Framework Convention on Climate Change (UNFCCC). Indonesia telah menandatangani berbagai kerjasama internasional di bidang lingkungan hidup dan pinjaman luar negeri dengan agenda untuk menurunkan emisi gas rumah kaca

2 J. Fitzgibbon dan K. Mensah, "Climate Change as a Wicked Problem", SAGE Open, Vol 2, No. 2 (2012), hal. 2

3 R. Grundmann, R, "Climate change as a wicked social problem", Nature, Geoscience, Vol 9, No. (8), (2016), hal. 562

4 J. Fitzgibbon dan K. Mensah, loc. cit., hal. 2 
di tingkat nasional sebesar 21\% tanpa bantuan dana internasional, dan 41\% dengan dana internasional, khususnya di bidang kehutanan. ${ }^{5}$ Terhitung sejak tahun 2011, misalnya, Indonesia telah meminjam dari Asian Development Bank sebesar \$US 100 juta $^{6}$ dan World Bank sebesar \$US 200.000,7 untuk berbagai kegiatan terkait manajemen penurunan emisi gas rumah kaca di Indonesia. Namun hingga saat ini hasilnya masih belum memuaskan, terutama dari program REDD,$+{ }^{8}$ sedangkan dampak perubahan iklim di Indonesia semakin jelas dan berbahaya.

Perubahan iklim merupakah salah satu isu global yang dibingkai sebagai isu yang dibedah dengan sistem antar pemerintah yang telah diatur oleh negara-negara lain memiliki kepentingan bersama (intergovernmental regime). Salah satu hasil dari sistem ini adalah Intergovernmental Panel of Climate Change (IPCCC) yang telah mengeluarkan beragam laporan dan manual untuk diikuti negara-negara anggota guna menurunkan emisi karbon mereka, termasuk Indonesia. Salah satu anjuran

5 Direktorat Jenderal Pengendalian Perubahan Ikim, Indonesia-Norway Partnerships on REDD+, Liputan Khusus COP 21 2015, http://ditjenppi.menlhk.go.id/program/liputan-khususcop-21-2015/indonesia-norway-partnerships-on-redd.html, diakses pada 13 April 2017

6 Asian Development Bank, News Releases, ADB \$100 Million Loan Aids Low Carbon Growth, Climate Resilience in Indonesia, https://www.adb.org/news/adb-100-million-loan-aidslow-carbon-growth-climate-resilience-indonesia, diakses pada 5 April 2017

7 World Bank, Projects and Operations, Indonesia Climate Change Development Policy Project, http://projects.worldbank.org/P120313/indonesia-climate-change-development-policy-project?lang=en, diakses 30 Maret 2017

8 Norwegia telah menyatakan ketidakpuasannya sebab tidak adanya kemajuan yang telah dicapai Indonesia dalam program REDD+. Pada tahun 2010, Norwegia setuju untuk menyerahkan dana sebesar US \$ 1 miliar kepada Indonesia untuk mendanai program pengurangan emisi terkait sektor kehutanan dan tanah gambut. Menteri Lingkungan dan Iklim Norwegia, Vidar Helgesen, dalam kunjungannya di bulan Febuari 2016, mengungkapkan apresiasinya terhadap pemerintah Indonesia dalam upaya pengurangan emisi dari sektor kehutanan dan lahan gambut, namun Helgesen menyayangkan kualitas implementasi program REDD+ yang rendah dan progressnya yang lambat. Sumber: Jakarta Post, 2016, Norway Slams Slow REDD+ Project Progress, http://www.thejakartapost.com/news/2016/02/04/norwayslams-slow-redd-project-progress.html, diakses 20 Mei 2017

9 Menurut penelitian sebelumnya, Indonesia dinilai menujukkan performa kinerja REDD+ yang lebih baik dibandingkan dengan negara REDD+ lainnya seperti Vietnam, Peru, dan Cameroon. Biarpun demikian, Indonesia masih menghadapi banyak kekurangan dalam kesiapan program REDDD+. Sebagai contoh, penelitian ini melihat bahwa tanggung jawab institusi dalam menjalankan program REDD+ masih belum jelas hingga perlu dipertimbangkan alternatif. Kemudian tidak ada prosedur MRV yang disiapkan oleh pemerintah, serta skema pembiayaan yang jelas - padahal Norwegia sudah menyediakan dana dengan jumlah yang besar untuk progam REDD+. Lihat Minang, Peter Akong, Meine Van Noordwijk, Lalisa A. Duguma, Dieudonne Alemagi, Trong Hoan Do, Florence Bernard, Putra Agung, et al. "REDD+ Readiness Progress Across Countries: Time for Reconsideration." Climate Policy 14, no. 6 (2014): hal 685-708. 
IPCC adalah menggunakan pendekatan multi-level governance (MLG), ${ }^{10}{ }^{11}$ seperti yang telah diterapkan di Uni Eropa. IPCC menganjurkan MLG sebab sebagai pendekatan dalam studi ilmu pemerintahan, pendekatan ini merupakan sebuah model tata kelola pemerintahan yang sesuai untuk program-program dengan tema pembangunan berkelanjutan (sustainability) dan kemudian juga penerapannya di bidang lain seperti perlindungan iklim atau ekonomi hijau. ${ }^{12}$ Serta dalam penerapannya, pendekatan MLG lebih menekankan pada aspek kerja sama antar lembaga yang meminimalisir birokrasi kelembagaan yang pada implementasinya banyak memperlambat program-program pemerintahan dan inisiatif masyarakat.

Pada tahun 2011 Indonesia meluncurkan rencana aksi nasional (RAN-GRK) untuk mengurangi emisi dari kehutanan dan sektor penggunaan lahan masingmasing sebesar $26 \%$ dan $41 \%$ pada tahun 2020. Namun pendekatan yang dipakai masih belum menggunakan MLG, seperti anjuran IPCC. Pendekatan yang dipakai dalam pengembangan dan implementasi kebijakan perubahan iklim di Indonesia masih dipengaruhi oleh sistem politik desentralisasi yang kemudian pada praktiknya justru membatasi otoritas dan partisipasi daerah dalam politik internasional seperti perubahan iklim. ${ }^{13}$ Berbeda dengan desentralisasi, MLG menawarkan sebuah sistem tata kelola yang partisipatif dan inklusif.

Suatu perubahan dari tata kelola yang tersentralisasi menjadi terdesentralisasi bukanlah suatu langkah yang mudah karena desentralisasi dapat diinterpretasikan secara berbeda oleh pihak-pihak yang berbeda. Di sektor kehutanan, sejumlah pemerintah daerah telah menginterpretasikan desentralisasi sebagai kebebasan sepenuhnya untuk melakukan apapun yang mereka inginkan dengan sumberdaya hutan di wilayah mereka. Salah interpretasi tak pelak

10 Kirsten Jörgensen, Anu Jogesh, dan Arabinda Mishra. "Multi-level climate governance and the role of the subnational level." Journal of Integrative Environmental Sciences no. 4, (2015), hal. 236

11 Kirsten Jörgensen, Barbara Saerbeck, dan Martin Janicke. "The Multi-Level System of Global Climate Governance - the Model and its Current State." Environmental Policy and Governance, 2, 27, (2017), hal. 109

12 Schreurs MA, Tiberghien Y. Multi-level reinforcement: explaining European Union leadership in climate change mitigation. Global Environmental Politics, 7,4, (2007), hal: 19-46. DOI:10.1162/glep.2007.7.4.19

13 Carol J. Pierce Colfer dan Doris Capistrano, eds, Politik Desentralisasi Hutan, Kekuasaan dan Rakyat Pengalaman di berbagai Negara, (Bogor: Center for InternationalForestry Research (CIFOR), 2006), hal. 
lagi membahayakan keberadaan sumberdaya hutan. ${ }^{14}$

Studi ini dikembangkan dengan mempelajari berbagai dokumen pemerintah dan penelitian sebelumnya seputar kebijakan perubahan iklim di Sumatera Utara 2011-2015, sebelum isu perubahan iklim diikutsertakan ke dalam implementasi agenda Sustainable Development Goals (SDGs) dan NAWA CITA. Adapun dokumendokumen strategis yang digunakan antara lain Rencana Aksi Daerah Penurunan Emisi Gas Rumah Kaca Provinsi Sumatra Utara 2010-2020 serta Peraturan Daerah Provinsi Sumatera Utara Tentang Rencana Pembangunan Jangka Panjang Daerah (RPJPD) Provinsi Sumatera Utara Tahun 2005 - 2025.

Pertimbangan untuk menganalisis kedua dokumen ini adalah karena kedua dokumen ini membahas detail penting tentang pelaksanaan kebijakan pengurangan emisi di kawasan Sumatera Utara. Sebagai pembanding antara kemajuan dari kebijakan ini dengan keadaan di lapangan, penelitian ini juga menganalisis laporan evaluasi kebijakan program pengurangan emisi baik dari eksternal maupun internal pemerintah. Tidak hanya itu, studi ini juga menganalisis pemberitaan di media massa Indonesia khususnya dari periode 2011-2015 untuk melihat bagaimana implementasi program di lapangan.

Jika melihat perkembangan yang signifikan sebagai implikasi dari agenda SDGs dan NAWA CITA di Indonesia dan data sekunder yang digunakan, maka studi ini akan terlihat tertinggal waktu. Oleh sebab itu, kedua hal diatas menjadi batasan dari studi ini. Biarpun demikian, argumen dan data sekunder yang digunakan dalam studi ini berkontribusi kepada pembelajaran implementasi sebuah kebijakan yang secara global diakui sulit dengan menganalisis konteks politik lokal di Indonesia. Penelitian ini disususun untuk memberikan latar belakang teoritis untuk memahami tentang tantangan tata kelola kebijakan perubahan iklim di Indonesia. Adapun tujuan ini berusaha dicapai dengan membandingkan dua pendekatan teoritis, yaitu desentralisasi dan MLG, serta penerapannya di negaranegara lain untuk kemudian dibandingkan dengan kondisi di Indonesia.

14 Wandojo Siswanto dan Wahjudi Wardojo, “Desentralisasi Sektor Kehutanan: Pengalaman Indonesia" dalam Carol J. Pierce Colfer dan Doris Capistrano, eds, Politik Desentralisasi Hutan, Kekuasaan dan Rakyat Pengalaman di berbagai Negara, (Bogor: Center for InternationalForestry Research (CIFOR), 2006) 


\section{Pendekatan Multilevel Governance (MLG)}

MLG merupakan sebuah pendekatan tata kelola yang identik dengan sistem pemerintahan Uni Eropa yang berawal sejak awal tahun 1990 -an. ${ }^{15}$ Kata kunci yang penting dari teori dan pendekatn MLG adalah kolaborasi. ${ }^{16}$ Bache dan Flinders (2004) menggunakan konsep MLG untuk memahami hubungan timbal balik dinamis di dalam dan di antara berbagai tingkat pemerintahan dan pemerintahan. ${ }^{17}$ Meskipun gagasan tentang tata kelola multilevel pada awalnya dikembangkan di sekitar Uni Eropa, banyak bentuknya telah diterapkan di bidang studi lain seperti studi negara-negara federal dalam politik komparatif. McCormick berpendapat bahwa "tata kelola bertingkat adalah sepupu konseptual dari dua konsep lama lainnya, federalisme dan konfederelisme" ${ }^{18}$ MLG juga dapat dipahami sebagai sebuah sistem pemerintahan polisentrik yang berarti sebuah sistem pemerintahan yang mana setiap bagian yang terlibat didalamnya tidak melihat sistem tersebut sebagai tantangan, namun sebagai sebuah inovasi, proses pembelajaran, serta bauran teknologi untuk mendukung instrumen kebijakan. ${ }^{19}$

Terdapat dua jenis MLG. ${ }^{20}$ Tipe I merupakan pendekatan hierarkis yang berfokus pada cara kompetensi dan otoritas dibagi antara berbagai tingkat pemerintahan; Tipe II merupakan model polisentrik di mana beberapa bidang otoritas horizontal yang saling tumpang tindih dan saling berhubungan terlibat dalam mengatur isu-isu tertentu. Sebagai sebuah sistem tata kelola lingkungan, MLG sangat penting karena beberapa alasan, antara lain: (1) sifatnya yang terintegrasi dari global hingga lokal; (2) Peran masing-masing level - dari global ke lokal - sangat spesifik; (3) Interaksi vertikal menawarkan potensi tambahan MLG

15 Literatur tentang konsep MLG dapat dilihat di Marks, 1993; Scharpf, 1997; Benz and Eberlein, 1999; Börzel and Risse, 2000; Hooghe and Marks, 2001; Kern, 2010

16 Coopenergy, What is Multi-Level Governance? http://www.coopenergy.eu/book/whatmulti-level-governance, diakses 25 Juli 2017

17 Kern K, Bulkeley H, “Cities, Europeanization and multi-level governance: governing climate change through transnational municipal networks". JCMS: Journal of Common Market Studies Vol 47, No. 2, hal 309-332.

18 M. Jänicke, M, M. Schreurs, dan K. Töpfer, 2015, The Potential of Multi-Level Global Climate Governance, https://goo.gl/XLiz8v, diakses 29 Mei 2017

19 Lihat K. Sovacool, "An International Comparison of Four Polycentric Approaches to Climate and Energy Governance", Energy Policy, Vol. 39, No. 6 (2015), hal. 3832-3844.

20 L. Hooghe dan G. Marks, "Types of Multi-Level Governance", European Integration Online Papers (EIoP), Vol. 5, No. 11, (2011), hal. 4-6 
sebagai sebuah sistem; (4) Multi-sektoral dan multi-stakeholder. ${ }^{21}$ Adapun ilustrasi dari kedua tipe MLG dan relasi antar aktor, tingkat yuridiksi, permasalahan yang diatur dapat dilihat dalam gambar dibawah ini:

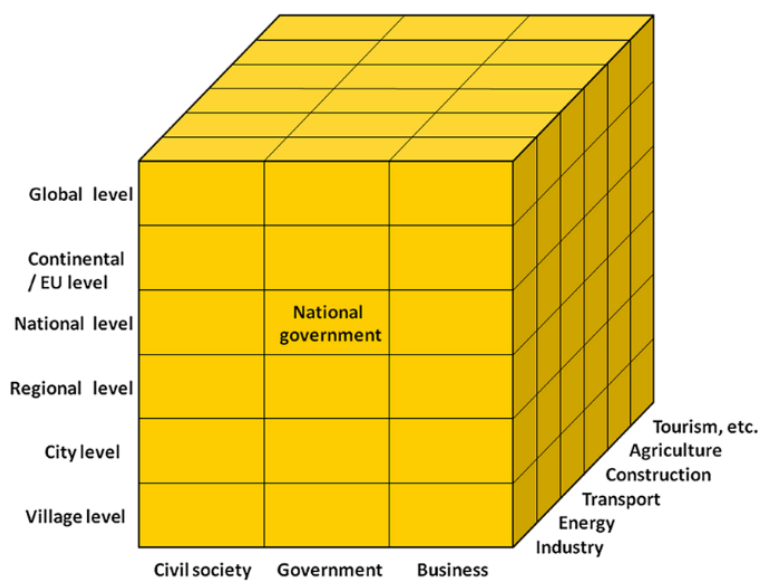

Gambar 1 'Model Rio' dari tata kelola pemerintahan multi-level dan multi-sektor yang berkelanjutan ${ }^{22}$

Ilustrasi diatas menggambarkan bagaimana pembangunan berkelanjutan dan juga perlindungan iklim memerlukan pendekatan pendekatan global. Tata kelola global, bagaimanapun, membutuhkan pemerintah pada tingkat nasional hingga lokal yang menjadi bagian dari sistem politik global. Peran masing-masing level - dari global ke lokal - sangat spesifik. Pemerintah dari tiap tingkat memiliki tanggung jawab, tantangan dan peluang tersendiri dan memiliki dinamika horizontal yang spesifik: pembelajaran, kompetisi dan kerja sama antar lembaga. Jaringan horizontal kota dan provinsi / negara bagian telah menjadi pemain global dalam tata kelola iklim. Interaksi vertikal menawarkan potensi tambahan MLG sebagai sebuah sistem: peningkatan praktik terbaik melalui kebijakan dan dukungan kebijakan tingkat tinggi terhadap tingkat yang lebih rendah. Interaksi MLG vertikal dan horizontal telah menjadi pusat dari pembelajaran interaktif yang tinggi dan difusi inovasi teknis dan politik yang cepat. ${ }^{23}$ Ini pada dasarnya adalah

21 M. Jänicke, "The Multi-Level System of Global Climate Governance - the Model and Its Current Status", Environmental Policy and Governance, Vol. 27, (2017), hal 110-111

22 Gambar diambil dari M. Jänicke, “The Multi-Level System of Global Climate Governance the Model and Its Current Status", Environmental Policy and Governance, Vol. 27, (2017), hal 110

23 Ibid., hal. 112-114 
sistem multi-impuls untuk inovasi terkait perubahan iklim. Hal ini menjadikan MLG sebagai sebuah model yang tidak hanya dapat menangani semua skala tetapi juga semua kelompok kepentingan terkait dalam tata kelola iklim global. Hal ini diilustrasikan sebagai berikut:

\begin{tabular}{|l|l|}
\hline \multicolumn{1}{|c|}{ Tingkat Pemerintah } & \multicolumn{1}{|c|}{ Peran } \\
\hline Global & $\begin{array}{l}\text { Badan-badan internasional seperti United Nations Environment } \\
\text { Programme (UNEP) dan Commission on Sustainable Development } \\
\text { berperan sebagai badan yang mengatur agenda kebijakan iklim global } \\
\text { untuk kemudian diteruskan ke negara anggota }\end{array}$ \\
\hline Negara persatuan & $\begin{array}{l}\text { Memainkan peran dalam artikulasi supranasional untuk kepentingan } \\
\text { bersama dan pembahasan solusi untuk masalah umum di wilayah ini }\end{array}$ \\
\hline Nasional & $\begin{array}{l}\text { Memiliki tanggung jawab khusus dalam pelaksanaan kebijakan } \\
\text { nasional. }\end{array}$ \\
\hline Provinsi/ Daerah & $\begin{array}{l}\text { Ini adalah level dimana sebagian besar peraturan nasional harus } \\
\text { dilaksanakan }\end{array}$ \\
\hline Masyarakat & Penggerak inisiatif / ide teknologi/gaya hidup ramah lingkungan \\
\hline Individu & $\begin{array}{l}\text { Anggota tata kelola dan sasaran dan dasar dari pengetahuan iklim } \\
\text { global (misalnya, laporan IPCC) }\end{array}$ \\
\hline
\end{tabular}

Tabel 1 Peran tiap aktor dalam sistem tata kelola MLG menurut Jänicke (2017)

Kriteria kesuksesan implementasi dapat dilihat dari enam faktor, ${ }^{24}$ antara lain: (1) Visi bersama (shared vision); (2) Kerja sama efektif (effective partnership); (3) Keterlibatan pemangku kepentingan (stakeholder involvement); (4) Ketersediaan dana (funding availability); (5) Keahlian teknis (technical expertise); (6) Tata kelola pemerintahan yang terstruktur (structured governance).

Beberapa contoh implementasi MLG yang sukses dapat dilihat dalam upayaupaya pengembangan kebijakan perubahan iklim yang terintegrasi di negaranegara Eropa. Sebagai contoh, Perjanjian Convenant of Mayors yang dipelopori oleh para walikota di kawasan Rhine-Neckar Metropolitan dinyatakan sebagai salah satu contoh penerapan MLG yang sukses dalam kategori tata kelola pemerintahan yang terstruktur (structured governance). Menurut laporan Coopenergy Eropa, ${ }^{25}$

24 Coopenergy, Good Practice Resources, http:/ / www.coopenergy.eu/good-practice-resources, diakases 20 Juli 2017

25 Coopenergy, Rhine-Neckar Metropolitan Region-Promotion of the Covenant of Mayors, http://www.coopenergy.eu/sites/default/files/good_practice_files/27_Rhine-Neckar\%20 Metropolitan\%20Region\%2C\%20DE\%20\%20Promotion \%20of \%20the \%20Covenant $\% 20$ of\%20Mayors.pdf, diakses pada 20 Juli 2017 
kesuksesan ini dinilai dari keberhasilan para mayor dalam kawasan tersebut dalam menghasilkan sebuah perjanjian yang mengikat seluruh mayor dalam kawasan Metropolitan tersebut. Adapun tujuan dari perjanjian ini adalah untuk mengimplementasikan kebijakan perubahan iklim serta melibatkan pemangku kepentingan (dari pihak swasta) dalam menjalan rencana menurunkan emisi kotakota mereka-seluruh kegiatan perencanaan dan pertemuan resmi tidak memiliki anggaran sehingga inisiatif ini dinilai lebih efisien dan efektif.

Swedia juga dinilai telah menerapkan program kebijakan perubahan iklim dengan pendekatan MLG dengan sangat baik, terutama dari segi kerjasama yang efektif. ${ }^{26}$ Contohnya adalah perwujudan inisiatif Sustainable Energy Community (SEC) of Kalmar County merupakan inisiatif MLG dari proyek European City. Melalui inisiatif ini, Badan Energi untuk Swedia Tenggara mendukung 5 dari 12 kota di Kalmar untuk menjadi ‘komunitas energi berkelanjutan' yang mengurangi emisi CO2 oleh setidaknya 30\% pada tahun 2030. Kolaborasi ini diformalkan melalui penandatanganan dokumen strategis serta policy tool kit yang disusun oleh masyarakat itu sendiri. Pengalaman SEC Kalmar ini menunjukkan pentingnya pembangunan kapasitas di tingkat masyarakat untuk membuat kebijakan, hingga kolaborasi di kalangan pegawai pemerintahan dan pakar teknis guna mewujudkan komitmen politik dalam pengembangan kebijakan perubahan iklim di tingkat lokal. Strategi pemberdayaan masyarakat dan pemerintah tingkat lokal ini tidak hanya menghasilkan data yang lebih baik guna memantau perkembangan kebijakan perubahan iklim yang sudah dibuat bersama tersebut, namun juga memastikan bahwa kebijakan yang dibuat menjawab permasalahan nyata di lingkungan masyarakat.

\section{Desentralisasi : tantangan MLG}

Desentralisasi dapat dipahami sebagai 'penyerahan kewenangan politik, keuangan dan administrasi dari pemerintah pusat ke daerah (kabupaten atau

26 Coopenergy, Southeast Sweden - Sustainable Energy Community of 5 municipalities in Kalmar County,http://www.coopenergy.eu/sites/default/files/good_practice_files/150_ Southeast $\% 20$ Sweden $\% 20 \%$ E2 $\% 80 \% 93 \% 20$ Sustainable $\% 20$ Energy $\% 20$ Community $\% 20$ of $\% 205 \% 20$ municipalities\%20in\%20Kalmar\%20County.pdf, diakses pada 20 Juli 2017 
kota) sehingga pemerintah dapat menyediakan dan menjamin pelayanan publik yang lebih baik bagi masyarakat'. ${ }^{27}$ Terdapat beberapa faktor-faktor pendukung kesusksesan sistem desentralisasi, antara lain: (1) Lembaga dan sumber daya manusia (SDM) yang memiliki kualifikasi untuk mengimplementasikan program dalam sistem desentralisasi; (2) Infrastruktur, teknologi, akses informasi, SDM, kapasitas kelembagaan dalam perencanaan, dan distribusi keuntungan sumberdaya alam yang layak. ${ }^{28}$

Konsep desentralisasi, telah menjadi strategi bagi berbagai negara untuk menjaga kelestarian lingkungan, untuk menjaga distribusi sumber daya dan kekuasaan hingga ke tingkat masyarakat yang sesuai dengan semangat demokrasi, pluralisme, dan persamaan hak. ${ }^{29}$ Penelitian sebelumnya menunjukkan bahwa desentralisasi justru menghambat perkembangan kebijakan perubahan iklim sebab, antara lain: (1) Hubungan birokrasi antar tingkatan pemerintah dalam sistem desentralisasi (federalisme) kompleks dan temuan di lapangan menujukkan bahwa justru memperlambat progress kebijakan perubahan iklim di daerah dan nasional ${ }^{30}$; (2) Dalam sistem desentralisasi (federalisme) terdapat pengaruh kuat dari partai politik dari pemerintahan yang berkuasa, sehingga tidak jarang membatasi gerak inisatif politik lingkungan yang bertentangan dengan kepentingan politik partai yang mendominasi sistem pemerintahan ${ }^{31}$; (3) Kurang pekanya pemerintah pusat (federal) terhadap isu sosial, politik, serta budaya masyarakat daerah sehingga kebijakan yang dibuat justru tidak sesuai dengan kebutuhan atau kebiasaan lokal ${ }^{32}$.

Studi tentang kebijakan perubahan iklim di sektor undang-undang bangunan (building policy) di Austria berargumen bahwa sistem tata kelola perubahan iklim

27 Carol J. Pierce Colfer dan Doris Capistrano, eds, Politik Desentralisasi Hutan, Kekuasaan dan Rakyat Pengalaman di berbagai Negara, (Bogor: Center for International Forestry Research (CIFOR), 2006), hal. 178

28 Ibid

29 Agrawal, Arun dan Elinor Ostrom. "Collective Action, Property Rights, and Decentralization in Resource use in India and Nepal." Politics \& Society 29, no. 4 (2001), hal. 487

30 Steurer, Reinhard, and Christoph Clar. "Is decentralisation always good for climate change mitigation? How federalism has complicated the greening of building policies in Austria." Policy Sciences 48, no. 1 (March 2015): 85-107. Business Source Ultimate, hal. 99-100

31 Rabe, Barry. "Contested Federalism and American Climate Policy." Publius: The Journal of Federalism 41, no. 3 (June 2011): 494-521. Political Science Complete, hal. 518

32 E. Ampaire, L. Jassogne, H. Providence, M. Acosta, J. Twyman, L. Winowiecki, dan P. Asten, "Institutional challenges to climate change adaptation: A case study on policy action gaps in Uganda". Environmental Science \& Policy, Vol. 75, hal. 88 
yang terdesentralisasi justru cenderung menyulitkan, sebab hubungan birokrasi antar tingkatan pemerintah dalam sistem desentralisasi (federalisme) kompleks serta justru memperlambat progress kebijakan perubahan iklim di daerah dan nasional ${ }^{33}$. Misalnya dalam kasus kebijakan bangunan Austria, Menteri Lingkungan di tingkat federal (pusat) dikonfrontasi oleh dua menteri lainnya dan sembilan kepala provinsi, kebijakan bangunan justru menjadi terbentur di tengah jalan karena kemudian mendapat tentangan dari pihak provinsi yang kemudian hanya melakukan sebatas keharusan administratif. Menteri Lingkungan Austria kemudian kesulitan untuk menjalankan agenda perubahan iklimnya, karena tanggung jawab menjalankan kebijakan tersebut ada di kementerian lain.

Selain itu, politik perubahan iklim akan dipengaruhi oleh politik pemerintah federal, sehingga rentan gagal jika tidak didukung oleh pemerintah federal dan kekuatan partai politik di belakangnya, walaupun publik mendukung isu, seperti di Amerika Serikat. ${ }^{34}$ Kebijakan perubahan iklim Amerika Serikat dibawah kepemimpinan George Bush, Jr., Barrack Obama, dan Donald Trump mengalami masa-masa kritis yang akhirnya diperburuk dengan keputusan Donald Trump untuk menutup Environmental Protection Agency Amerika Serikat, departemen utama di tingkat federal dan lokal yang berfokus memanajemen urusan perubahan iklim dan lingkungan di Amerika Serikat. ${ }^{35}$ Partai Republikan merupakan partai politik terbesar yang selalu menentang kebijakan perubahan iklim dengan alasan akan merugikan industri Amerika Serikat. Partai Demokrat juga tidak lebih progresif dari Republikan, malah figur-figur penting dari Demokrat seperti Barrack Obama dan Hillary Clinton justru tidak mampu mendorong isu perubahan iklim di partai mereka sendiri. ${ }^{36} 37$

33 Steurer, R., dan C. Clar,"Is Decentralisation Always Good for Climate Change Mitigation? How Federalism Has Complicated the Greening of Building Policies in Austria", Policy Sciences, (2015), Vol. 48, hal. 94

34 Koski, C., dan A. Siulagi, “Environmental harm or natural hazard? Problem identification and adaptation in U.S. municipal climate action plans." The Review of Policy Research No. 3: (2016), hal. 270-290

35 http://edition.cnn.com/2017/04/29/politics/trump-epa-cuts-infighting-climate-change/ index.html

36 Naomi Klein, Opinion, We're out of time on climate change. And Hillary Clinton helped get us here, https://www.theguardian.com/commentisfree/2016/apr/07/out-of-time-climate-change-hillary-clinton, diakses 25 Juli 2017

37 Naomi Klein, Opinion, Climate change is a global emergency. Stop waiting for politicians to sound the alarm, https://www.theguardian.com/commentisfree/2014/sep/20/climatechange-global-emergency-alarm, diakses 25 juli 2017 
Studi di Uganda, misalnya, adalah sebuah contoh tata kelola perubahan iklim yang tidak efektif dan berakibat pada ketidaksuksesan program kebijakan iklim mereka. Selama lebih dari satu dekade pemerintah nasional telah mengatur banyak peran yang harus dimainkan oleh pemerintah daerah seperti, (i) menunjuk dan memberi penghargaan kepada para pemimpin kabupaten, (ii) menghapuskan sumber pendapatan tingkat daerah, dan (iii) mengalokasikan anggaran kecil ke sektor non-produktif. Hal ini menempatkan kabupaten pada tahap penerimaan, tanpa mengambil keputusan. Juga, mereka tidak berada dalam posisi untuk meminta para pejabat untuk bertanggung jawab, yang telah melakukan "hubungan patron-klien" antara pemerintah pusat dan pemimpin lokal. ${ }^{38}$

Sedangkan di Indonesia, penelitian Siswanto dan Wardojo menemukan beberapa permasalahan penting dari praktik desentralisasi di sektor tata kelola kehutanan di Indonesia. Penelitian ini menemukan beberapa permasalahan krusial dalam sektor pemerintahan yang berbeda, seperti: (1) Birokrasi pusat-daerah; (2) Perundangan; (3) Pemerintah lokal/ masyarakat. Menurut penelitian ini, memahami semangat dari otonomi, implementasi desentralisasi kehutanan seharusnya tidak terperangkap dalam permasalahan otoritas kewenangan antara pusat-daerah $^{39}$. Misalnya saja, di tingkat provinsi dan kabupaten, status hierarkis di sektor publik sering membatasi pegawai negeri eselon yang lebih rendah untuk mengkoordinasikan atau mengarahkan kepala lembaga lain dengan status eselon yang lebih tinggi. ${ }^{40}$ Namun harus tetap berpijak dari semangat membangun kesejahteraan sosial bagi rakyat dan pencapaian pengelolaan hutan yang berkelanjutan. ${ }^{41}$

Studi ini juga berargumen bahwa kedua dimensi tersebut dapat dicapai melalui koordinasi dan kesatuan visi yang sama antara pusat dan daerah. Batasan

38 E. Ampaire, L. Jassogne, H. Providence, M. Acosta, J. Twyman, L. Winowiecki, dan P. Asten, loc. cit., hal. 86

39 Wandojo Siswanto dan Wahjudi Wardojo, “Desentralisasi Sektor Kehutanan: Pengalaman Indonesia” dalam Carol J. Pierce Colfer dan Doris Capistrano, eds, Politik Desentralisasi Hutan, Kekuasaan dan Rakyat Pengalaman di berbagai Negara, (Bogor: Center for InternationalForestry Research (CIFOR), 2006), hal 178-179

40 J. McCarthy dan Z. Zen, "Regulating the Oil Palm Boom: Assessing the Effectiveness of Environmental Governance Approaches to Agro-Industrial Pollution in Indonesia", Law amd Policy, Vol. 32, No. 1 (2010), hal. 153-179.

41 Wandojo Siswanto dan Wahjudi Wardojo, Op.cit., hal. 178 
administratif seharusnya tidak menjadi penghalang dalam pengelolaan di sektor kehutan. Sebaliknya pemerintah, swasta, dan masyarakat harus saling bekerja sama untuk mencapai kesejahteraan sosial dari hasil hutan tersebut melalui programprogram yang berkelanjutan. Kegagalan sistem politik desentralisasi kehutanan di Indonesia dapat dilihat dari lambatnya birokrasi di sektor kehutanan, munculnya konflik di antara berbagai pemangku kepentingan akibat kompleksitas permasalahan di lapangan serta kesalahan dalam menafsirkan model pengelolaan hutan, juga terjadinya degradasi hutan. ${ }^{42}$ Adapun beberapa hambatan dari sistem politik desentralisasi terhadap pengelolan sektor kehutanan di Indonesia dapat dilihat dalam tabel berikut:

\begin{tabular}{|l|l|}
\hline \multicolumn{1}{|c|}{ Tingkat Pemerintah } & \multicolumn{1}{|c|}{ Peran } \\
\hline Global & $\begin{array}{l}\text { Badan-badan internasional seperti United Nations Environment } \\
\text { Programme (UNEP) dan Commission on Sustainable Development } \\
\text { berperan sebagai badan yang mengatur agenda kebijakan iklim global } \\
\text { untuk kemudian diteruskan ke negara anggota }\end{array}$ \\
\hline Negara persatuan & $\begin{array}{l}\text { Memainkan peran dalam artikulasi supranasional untuk kepentingan } \\
\text { bersama dan pembahasan solusi untuk masalah umum di wilayah ini }\end{array}$ \\
\hline Nasional & $\begin{array}{l}\text { Memiliki tanggung jawab khusus dalam pelaksanaan kebijakan } \\
\text { nasional. }\end{array}$ \\
\hline Provinsi/ Daerah & $\begin{array}{l}\text { Ini adalah level dimana sebagian besar peraturan nasional harus } \\
\text { dilaksanakan }\end{array}$ \\
\hline Masyarakat & Penggerak inisiatif / ide teknologi/ gaya hidup ramah lingkungan \\
\hline Individu & $\begin{array}{l}\text { Anggota tata kelola dan sasaran dan dasar dari pengetahuan iklim } \\
\text { global (misalnya, laporan IPCC) }\end{array}$ \\
\hline
\end{tabular}

Tabel 2 : Hambatan Dari Sistem Politik Desentralisasi Terhadap Sektor Kehutanan di berbagai Negara, (Bogor: Center for InternationalForestry Research (CIFOR), 2006)

\section{Perkembangan kebijakan perubahan iklim Indonesia}

Indonesia adalah negara kepulauan dengan tiga puluh empat provinsi dimana berbagai tindakan dan rencana iklim yang berbeda direncanakan dan dilaksanakan secara berbeda dari satu provinsi dengan provinsi lainnya sebagai implementasi 
dari sistem pemerintahan terdesentralisasi. Keterlibatan Indonesia dalam politik internasional perubahan iklim sudah dimulai sejak tahun 1992 ketika perwakilan Indonesia menghadiri Konvensi Kyoto Protokol tahun 1992. Seiring dengan liberalisasi pasar Orde Baru, terjadi berbagai permasalahan lingkungan hidup akibat ekploitasi pertambangan, pembukaan lahan untuk perkebunan dan transmigrasi, serta pembangunan resot dan hotel, namun tidak banyak yang bisa dilakukan karena pengaruh besar Soeharto dan kroninya hingga pedesaan di Indonesia berbagai aktivitas ekonomi seperti eksploitasi pertambangan, pembukaan hutan untuk industri perkebunan, dan pembukaan lahan untuk industri pariwisata. ${ }^{43}$

Namun tidak banyak yang bisa dilakukan pada masa itu karena pengaruh Soeharto dan kroninya yang mengakar hingga pedesaan dan keterlibatan masyarakat dengan perkembangan politik lingkungan internasional bisa dikatakan minimal dan tidak signifikan. ${ }^{44}$ Komitmen internasional yang rendah ini memiliki implikasi negatif pada politik dan kebijakan lingkungan domestik. Sebaliknya, jika komitmen internasional yang tinggi akan berdampak positif pada kedua hal tersebut. Sebagai contoh, Uni Eropa yang memiliki komitmen yang tinggi terhadap lingkungan, seperti Jerman ${ }^{4546}$ dan Belanda, dengan komitmen politik yang tinggi terhadap politik lingkungan internasional memiliki kebijakan dan partisipasi masyarakat yang tinggi. ${ }^{47}$

43 G. Andrew, The floracrats: state-sponsored science and the failure of the Enlightenment in Indonesia, (Madison, Wis: University of Wisconsin Press, 2011), hal. 75

44 Colin MacAndrews, "Politics of the Environment in Indonesia", Asian Survey, Vol. 34, No. 4: 369 (1994), hal 373-380

45 Berlin, Jerman, bersiap-siap menghadapi dampak perubahan iklim dengan merancang kota mereka agar mampu menyerap air dan emisi karbon dengan memperbanyak lahan hijau dan mendorong masyarakat menanam tanaman yang menyerap air dan emisi karbon. Rencana Aksi Iklim Jerman 2050 (Klimaschutzplan 2050) adalah dokumen kebijakan perlindungan iklim yang disetujui oleh pemerintah Jerman pada tanggal 14 November 2016. Rencana tersebut menguraikan langkah-langkah yang dengannya Jerman dapat memenuhi berbagai tujuan pengurangan emisi gas rumah kaca nasionalnya sampai tahun 2050 dan memberikan komitmen internasionalnya berdasarkan Perjanjian Iklim Paris 2016. Lihat: Nils Zimmermann, "Sponge City: Berlin plans for a hotter climate", Deutsche Welle, http://www. dw.com/en/sponge-city-berlin-plans-for-a-hotter-climate/a-19420517, diakses pada 15 Maret 2017

46 Federal Ministry for the Environment, Nature Conservation, Building and Nuclear Safety, Climate Action Plan 2050: Principles and goals of the German's government climate policy, UNFCCC International, https://unfccc.int/files/focus/long-term_strategies/application/ pdf/161114_climate_action_plan_2050_en_bf.pdf, diakses pada 1 Maret 2017

47 Belanda mengintegrasikan agenda kebijakan iklim domestiknya ke dalam kebijakan luar negeri sebagai bentuk komitmen Belanda terhadap politik kebijakan iklim internasional. 
Pada tahun 2011, Pemerintah Indonesia meluncurkan rencana strategis untuk menurunkan emisi nasional Indonesia. Dokumen tersebut adalah RAN-GRK yang diturunkan dari COP21 di Bali dan Copenhagen Accord. RAN-GRK adalah dokumen strategis yang menjelaskan tentang strategi nasional untuk menurunkan emisi rumah kaca dari lima sektor, yaitu: konsumsi energi, transportasi, kehutanan dan lahan gambut, dan kegiatan rumah tangga. Adapun RAN-GRK merupakan kebijakan yang bersifat top-down sehingga fokus pengembangan hingga implementasi tersentral sejak di tingkat kementerian. ${ }^{48}$

Deforestasi di Indonesia terjadi pada tingkat yang mengkhawatirkan dan masalah ini telah terjadi Pusat Rencana Aksi Nasional Pengurangan Emisi Gas Rumah Kaca (RAN GRK). Pada 2011, Presiden Indonesia, Susilo Bambang Yudhoyono, berjanji untuk mengurangi emisi dari sektor kehutanan dan sektor pemanfaatan lahan masing - masing sebesar $26 \%$ dan $41 \%$ dari garis dasar Business as Usual (BAU) (berdasarkan dukungan bantuan internasional) pada tahun 2020. Untuk mencapai target tersebut, Indonesia mengikuti Intergovernmental Panel on Climate Change (IPCC) untuk mengembangkan Mitigasi yang Layak secara Nasional Tindakan (NAMAs) dan contoh kota-kota Eropa untuk menggunakan tata kelola iklim bertingkat sebagai pendekatan dalam mengembangkan dan menerapkan strategi mitigasi dan adaptasi iklim mereka.

COP-13 2007 Bali memiliki pengaruh yang besar bagi perkembangan kebijakan perubahan iklim di Indonesia. Hasil penting dari COP-13 antara lain dituangkan dalam Bali Action Plan yang mengatur skema pengurangan emisi dari deforestasi negara berkembang; pengembangan serta transfer teknologi yang didukung secara finansial oleh negara-negara maju. Kemudian hasil penting lainnya adalah keluarnya laporan Fourth Assessment Report of the Intergovernmental Panel on Climate

Tidak hanya itu, di tahun 2015 Pengadilan Tinggi Den Haag memenangkan gugatan hukum masyarakat kota Den Haag terhadap pemerintah kota sebab pemerintah kota dinilai bersalah tidak memenuhi tugas dan tanggung jawab mereka memitigasi dampak perubahan iklim atas kota mereka Inisiatif masyarakat, didukung oleh komitmen politik pemerintah menciptakan teknologi serta terobosan kebijakan perubahan iklim yang komprehensif dan Uni Eropa adalah negara kesatuan yang berhasil mewujudkannya. Lihat: Arthur Neslen, "Dutch government ordered to cut carbon emissions in landmark ruling", The Guardian, https://www.theguardian.com/environment/2015/jun/24/dutch-government-orderedcut-carbon-emissions-landmark-ruling, diakses pada 3 Maret 2017

48 BAPPENAS, Laporan Dua Tahun Pelaksanaan RAN-GRK dan RAD-GRK, http://ranradgrk.bappenas.go.id/rangrk/admincms/downloads/publications/Laporan_Dua_Tahun_Pelaksanaan_RAN-GRK_RAD-GRK.pdf, diakses 12 Febuari 2017 
Change. Selain itu Indonesia telah mengeluarkan undang-undang yang secara spesifik mengatur tentang mitigasi perubahan iklim.

Sebelumnya, Indonesia sudah memiliki beberapa undang-undang tentang perubahan iklim antara lain; Undang - Undang 1994 Nomor 6 Tahun 1994 Tentang Pengesahan United Nations Framework Convention on Climate Change (Konvensi Kerangka Kerja Perserikatan Bangsa-bangsa Mengenai Perubahan Iklim). Setelah COP-13, Indonesia kemudian mengeluarkan undang-undang perubahan iklim yang menjabarkan tentang peran pemerintah dalam prosesnya. Undang-undang Republik Indonesia nomor 16 Tahun 2016 tentang pengesahan Paris Agreement to The United Nations Framework Convention on Climate Change (Persetujuan Paris Atas Konvensi Kerangka Kerja Perserikatan Bangsa-Bangsa Mengenai Perubahan Iklim); Undang-undang Republik Indonesia Nomor 17 Tahun 2004 Tentang Pengesahan Kyoto Protocol To The United Nations Framework Convention On Climate Change (Protokol Kyoto Atas Konvensi Kerangka Kerja Perserikatan Bangsa-bangsa Tentang Perubahan Iklim); dan Undang-undang Republik Indonesia Nomor 31 Tahun 2009 Tentang Meteorologi, Klimatologi, Dan Geofisika (selanjutnya disebut “UU No. 31 Tahun 2009”). UU No. 31 Tahun 2009 menjadi landasan hukum yang kuat sebab undang-undang tersebut menjelaskan langkah-langkah apa saja yang harus diambil untuk mitigasi maupun adaptasi.

"Pemerintah wajib melakukan mitigasi dan adaptasi perubahan iklim. (2) Untuk mendukung mitigasi dan adaptasi sebagaimana dimaksud pada ayat (1), Pemerintah wajib melakukan: a) perumusan kebijakan nasional, strategi, program, dan kegiatan pengendalian perubahan iklim; b) koordinasi kegiatan pengendalian perubahan iklim; dan c) pemantauan dan evaluasi penerapankebijakan tentang dampak perubahan iklim"49

Melalui serangkaian kebijakan perubahan iklim tersebut, Indonesia telah menyiapkan beberapa dokumen strategis terkait penangangan dampak perubahan iklim yang berfokus pada mitigasi, adaptasi, serta pembiayaan program perubahan iklim di Indonesia. Sifat rencana strategis ini merupakan rencana strategis desentralisasi, yang mana implikasi kebijakan dalam sistem seperti ini memiliki tantangan dan potensi tersendiri di Indonesia.

49 Undang-undang Republik Indonesia Nomor 31, Tentang Meteorologi, Klimatologi, Dan Geofisika, tahun 2009, pasal 65 
Peraturan Presiden Nomor 61 Tahun 2011 mengatur tentang Rencana Aksi Nasional Penurunan Emisi Gas Rumah Kaca (Selanjutnya disebut dengan “Perpres No. 61 Tahun 2011”). Berdasarkan Perpres No. 61 Tahun 2011, RAN GRK tidak hanya mencakup kegiatan yang perlu dilakukan oleh pemerintah pusat, tetapi juga menjadi acuan bagi pemerintah daerah dan sektor swasta dalam perencanaan dan dukungan kegiatan penurunan GRK. Dalam hal ini, di beberapa provinsi juga memasukkan kegiatan mitigasi sebagai bagian dari RAD-GRK yang sebelumnya sudah tercantum dalam RAN-GRK. Usulan kegiatan RAD-GRK juga umumnya didesain untuk melibatkan sumber pendanaan tidak hanya dari APBD tetapi juga dari APBN dan BUMN ataupun dari sektor swasta. ${ }^{50}$ Kedua rencana aksi ini mengatur tentang rencana nasional dan daerah untuk menyusun data inventori emisi tiap daerah yang nantinya akan digunakan sebagai dasar penghitungan penurunan emisi nasional dan prioritas pembangunan daerah. Dalam rencana tersebut, setiap daerah diwajibkan merancang rencana penurunan emisi daerah mereka dengan tetap mengikuti prioritas pembangunan daerah. Sumber dana kegiatan RAD-GRK berasal dari berbagai sumber, termasuk APBN, APBD, swasta, masyarakat, hingga donor internasional..$^{51}$

\section{Tantangan Penerapan RAD GRK di Sumatera Utara}

Perspektif MLG menerangkan bahwa desentralisasi justru menghambat perkembangan kebijakan perubahan iklim di tingkat lokal. Oleh sebab itu, bagian ini akan membahas bagaimana tantangan RAD GRK di Sumatera Utara sebagai sebuah produk dari desentralisasi kebijakan di Indonesia. Sumatera Utara merupakan provinsi di Indonesia dengan laju kebakaran hutan yang cepat. Namun demikian, pada tahun 2011 Sumatera Utara mengumumkan menjadi salah satu provinsi pertama yang akan menjalankan RAD GRK, yang kemudian kebijakan mitigasinya difokuskan pada isu deforestasi. Kemudian strategi adaptasinya berfokus pada

50 Dari beberapa dokumen RAD-GRK, beberapa kegiatan bersifat usulan atau masih merupakan nonfundedactivities terkait dengan belum adanya komitmen dari segi pendanaan aktifitas.

51 Irfa Ampri, PhD, “Pendanaan Perubahan Iklim di Indonesia”, (makalah disampaikan dalam Diskusi Publik Kesiapan Indonesia Menghadapi Perundingan Perubahan Iklim Doha, 2012), hal. 7 
penguatan produksi padi dalam konteks perubahan iklim..$^{52}$ Untuk melaksanakan program adaptasi, pemerintah Sumatera Utara bekerja sama Japan International Cooperation Agency. Sumatera Utara merupakan salah satu provinsi di Indonesia yang berkomitmen untuk mengimplementasikan RAD-GRK di tahun $2011^{53}$. RADGRK Provinsi Sumatera Utara 2010-2020 telah disahkan dengan Peraturan Gubernur Sumatera Utara Nomor 36 Tahun 2012 tentang Rencana Pembangunan Jangka Panjang Daerah Provinsi Sumatera Utara Tahun 2005 - 2025. Sedangkan kebijakan adaptasi perubahan iklim dituangkan dalam strategi Upaya Pengamanan Produksi Beras di Sumatera Utara 2012-2020 yang telah disahkan dengan Intruksi Gubernur Sumatera Utara Nomor 188.54/05/INST/2012, yang juga merupakan turunan dari Pergub No. 36 tahun 2012. Kedua regulasi ini juga diintegrasikan kedalam RPJMD 2014-2018 yang mana pemantapan pembangunan secara menyuluruh dengan penekanan pada daya saing daerah, yang dilandaskan pada sumber daya manusia dan sumber daya alam, melalui pemanfaatan teknologi. Integrasi ini juga mendukung visi RPJPD Sumatera Utara 2005-2025 yaitu masyarakat Sumatera Utara yang Beriman, Maju, Mandiri, Mapan dan Berkeadilan di dalam ke Bhinnekaan yang didukung oleh tata pemerintahan yang baik.

Komitmen ini secara simbolik memiliki pengaruh yang positif bagi citra internasional Indonesia karena Sumatera Utara tercatat memiliki permasalahan kebakaran hutan, perubahan lahan, serta polusi udara dari transportasi dan kegiatan produksi pabrik yang tinggi. Untuk mengatasi permasalahan ini, pemerintah daerah Sumatera Utara mengadaptasi RAD-GRK dan telah sampai pada proses inventarisasi emisi lokal mereka. Namun proses ini terhenti di tengah jalan ketika Gubernur Sumatera Utara saat itu menjadi tersangka kasus korupsi. Hingga kini, belum banyak perkembangan signifikan dari RAD-GRK di Sumatera Utara.

Laporan kemajuan implementasi RAD GRK Sumatera Utara menguraikan empat masalah terkait pengawasan dalam pelaksanaan RAD GRK: 1) koordinasi yang buruk antar instansi pemerintah; 2) Sumatera Utara tidak dapat mengejar ketinggalan dengan pengembangan model persediaan emisi gas rumah kaca dari pemerintah nasional karena ketidakkonsistenan perencanaan, 3) Tidak ada

52 BAPPEDA Sumatera Utara, Rencana Aksi Daerah Penurunan Emisi Gas Rumah Kaca Provinsi Sumatra Utara 2010-2020, (Medan: BAPPEDA Sumatera Utara), hal. 6-10

53 BAPPENAS, Satu Tahun RAN-GRK, (Jakarta: BAPPENAS), hal. 23 
keharusan hukum bagi pemerintah daerah dan kota untuk memberikan inventoris tingkat emisi GRK mereka, sehingga sulit menyusun sebuah RAD-GRK yang berbasis bukti inventoris emisi rumah kaca; 4) terbatasnya sumber daya manusia yang mahir dalam perhitungan emisi gas rumah kaca. ${ }^{54}$

Seperti yang telah disebutkan di bagian sebelumnya, bahwa koordinasi antara pemerintah provinsi dan pemerintah pusat dapat menjadi tantangan nyata dalam iklim bertingkat atau pengaturan tata kelola lingkungan di Indonesia. Hal ini juga dialami di dalam implementasi RAD GRK di Sumatera Utara. Sebagai contoh, dalam hal pengelolaan limbah di Sumatera Utara, pemerintah kabupaten hanya fokus pada penanganan limbah daripada bekerja sama dengan tingkat pemerintahan dan bisnis lainnya untuk memastikan pengelolaan lingkungan dianggap sebagai 'keseluruhan masalah pemerintah' ${ }^{55}$

Kedua, masalah koordinasi dapat menyebabkan penundaan yang signifikan dalam pelaksanaan dan mengevaluasi program. Misalnya, menurut pedoman RAD GRK, Sumatera Utara telah menetapkan target untuk menghasilkan lebih banyak energi terbarukan di daerah-daerah terpencil antara tahun 2013 dan 2020. Namun, menurut survei Biro Statistik pada tahun 2015, masih ada 36 keluarga di Sumatera Utara yang tidak memiliki akses listrik. ${ }^{56}$ Pemerintah Sumatera Utara menjelaskan bahwa alasan di balik lambatnya pelaksanaan proses penyediaan masyarakat terpencil dengan akses terhadap energi terbarukan (misalnya panel surya) adalah karena Peraturan Menteri Energi dan Sumber Daya Mineral Republik Indonesia Nomor: 17 Tahun 2013 Tentang Pembelian Tenaga Listrik oleh PT. Perusahaan Listrik Negara (Persero) dari Pembangkit Listrik Tenaga Surya Fotovoltaik yang bedampak pada Perusahaan Listrik Nasional (PLN) daerah. ${ }^{57}$

54 Departemen Lingkungan Hidup Sumatera Utara, Pelaksanaan Inventarisasi Gas Rumah Kaca (GRK) di Provinsi Sumatera Utara, http:/ / lcs-rnet.org, diakses 14 Oktober 2015

55 BPS Sumatera Utara, Survei: Statistik Infrastuktur di Sumatera Utara.diakses 30 Maret 2017ns, In2001; era Utaraluarkan undang-undang perubahan iklim yang menjabarkan tentang peran pemerintah dalam https://sumut.bps.go.id/backend/pdf_publikasi/StatistikInfrastruktur-Sumatera-Utara-2014.pdf, diakses pada 10 Oktober 2015

56 BPS, Banyaknya Desa / Kelurahan Menurut Keberadaan Keluarga Pengguna Listrik dan Sumber Penerangan Jalan Utama Desa, https://www.bps.go.id/linkTabelStatis/view/ id/1759, diakses 20 Juli 2017

57 E. Siregar, "Pemerintah perlu dorong investasi energi di Sumatera Utara", http://www. antaranews.com/ diakses pada 12 Oktober 2015 
Ketiga, lemahnya komitmen politik dari pemerintah (dalam hal ini baik pusat maupun lokal) yang wujudnya adalah tidak ada keharusan pemerintah kabupaten untuk menyediakan data persediaan GRK, maka mengumpulkan data emisi dari tingkat kabupaten merupakan tugas yang sulit. Hal ini berdampak pada kualitas data inventaris emisi rumah kaca yang kemudian dikumpulkan ke pemerintah provinsi untuk kemudian diteruskan ke level nasional. Hal ini juga terkait dengan masalah keempat, yaitu hanya sedikit orang yang mengerti bagaimana melakukan akuntansi karbon di tingkat kabupaten. Dengan keterbatasan sumber daya manusia yang memahami pelaksanaan RAD GRK, ada kemungkinan besar gagal di tingkat kabupaten.

\section{Kesimpulan}

Sumatera Utara adalah salah satu provinsi di Indonesia yang pertama kali mengambil inisiatif untuk mengembangkan RAD-GRK pada masa awal inisasinya. Namun pada perjalanannya, RAD-GRK di Sumatera Utara justru mengalami stagnansi dan kemunduran. Melalui perspektif MLG, desentralisasi dilihat sebagai salah satu faktor penyebab kebijakan iklim gagal atau berjalan lambat di suatu daerah atau negara.

Di tingkat internasional, berbagai penelitian mencoba menjelaskan mengapa banyak negara gagal dalam menjalankan program mitigasi dan adaptasi perubahan iklim. Salah satu elemen yang diteliti adalah aspek tata kelola pemerintahan (governance), yang menunjukkan bahwa sistem yang terdesentralisasi cenderung membuat program mitigasi dan adaptasi iklim terhambat untuk beberapa alasan, antara lain: sifatnya yang sangat birokratis dan sedikit membuka cela bagi keterlibatan masyarakat serta tidak mampu mengakomodasi program yang sifatnya intranasional seperti, perubahan iklim

Untuk Indonesia sendiri, perubahan iklim menjadi penting ketika Sustainable Development Goals (SDGs) memasukkan perubahan iklim sebagai salah satu isu strategis SDGs di negara-negara berkembang pada tahun 2015. Hal ini melegitimasi isu perubahan iklim sebagai agenda penting dalam RPJM Indonesia hingga ke 
tingkat daerah. Hingga saat ini strategi mitigasi dan adaptasi perubahan iklim menjadi strategi penting guna mengurangi resiko bencana akibat perubahan iklim di berbagai daerah yang rentan.

Sejak tahun 2007, pemerintah Indonesia telah mengembangkan dua rencana aksi nasional (RAN-GRK) dan daerah (RAD-GRK) sebagai peta jalan penurunan emisi gas rumah kaca sesuai dengan anjuran IPCCC. Hal ini berdampak positif bagi citra Indonesia di panggung politik lingkungan internasional serta Indonesia juga mampu menarik dana internasional yang signifikan untuk mengembangkan dan melaksanakan program RAN GRK dan RAD-GRK. Indonesia telah menurunkan beberapa kebijakan dan undang-undang terkait perubahan iklim namun hasilnya belum signifikan karena Indonesia masih menghasilkan emisi yang mengkhawatirkan, seperti kebakaran hutan di Sumatera Utara tahun 2015. Maka tidak heran ketika pemerintah Indonesia juga mendapat kritik atas permasalahan kebakaran hutan, yang telah membuat komitmen perubahan iklim Indonesia sebagai agenda politik yang oportunistik dan tidak realistis.

RAN-GRK dan RAD-GRK dikembangkan berdasarkan pendekatan desentralisasi, serta belum memenuhi pendekatan tata kelola multilevel seperti yang dianjurkan oleh UNFCCC dan dicontohkan dalam tata kelola perubahan iklim di sejumlah wilayah di Eropa. Desentralisasi telah menciptakan faktor tambahan yang terbukti bermasalah bagi tata kelola iklim yang sukses di Indonesia, dan salah satu contohnya dapat dilihat pada penerapan kebijakan iklim di Sumatera Utara. Hambatan ini dapat dilihat dari beberapa aspek, antara lain: (1) Sistem desentralisasi tidak mendukung pendanaan yang tidak sesuai dengan kebijakan pemerintah pusat, padahal banyaknya kegiatan perubahan iklim di daerah membutuhkan pendanaan khusus dan berbeda dari daerah lainnya; (2) Desentralisasi telah menciptakan situasi yang lebih kompleks di mana koordinasi antara banyak pusat kekuasaan dan otoritas menjadi lebih sulit. Hal ini juga berdampak pada perencanaan koordinasi dan konsistensi; (3) Oleh karena karakteristik distribusi tanggung jawab tidak diikuti dengan peningkatan kapasitas masyarakat lokal secara teknis dan distribusi otoritas yang lebih besar di tingkat lokal juga tidak disertai dengan pengembangan keterampilan teknis yang sesuai di tingkat lokal untuk melaksanakan tugas yang diperlukan seperti pencatatan emisi gas rumah kaca yang akurat. 


\section{DAFTAR PUSTAKA}

Agrawal,A, danE. Ostrom. “Collective Action, Property Rights, and Decentralization in Resource Use in India and Nepal." Politics E Society No. 4 (2001): 485-514

Ampaire, Edidah L., Laurence Jassogne, Happy Providence, Mariola Acosta, Jennifer Twyman, Leigh Winowiecki, dan Piet van Asten. "Institutional challenges to climate change adaptation: A case study on policy action gaps in Uganda." Environmental Science and Policy Vol. 75, (2017): 81-90.

Andrea, Ciampani. "Social Europe as a Multilevel Governance: The Italian Perspective." Directory of Open Access Journals, Journal of Mediterranean Knowledge, Vol 1, Iss 1, Pp 65-77 (2016)

Bache, I, dan Matthew Flinders. Multi-level governance. Cheltenham: Edward Elgar Pub. Ltd, 2015

BAPPENAS, Laporan Dua Tahun Pelaksanaan RAN-GRK dan RAD-GRK, http:/ / ranradgrk.bappenas.go.id/rangrk/admincms/downloads/publications/ Laporan_Dua_Tahun_Pelaksanaan_RAN-GRK_RAD-GRK.pdf,

Benz, A, dan B Eberlein. "The Europeanization of regional policies: patterns of multi-level governance." Journal of European Public Policy, Vol. 6, No. 2 (1999): 329-348

Börzel, T., dan Risse, TH. Who is afraid of a European federation? How to constitutionalize a multi-level governance system? di dalam What Kind of Constitution for What Kind of Polity? Responses to Joschka Fischer, edited by Joerges C, Mény Y, Weiler JHH European University Institute: Florence, 2000 BPS, Banyaknya Desa / Kelurahan Menurut Keberadaan Keluarga Pengguna Listrik dan Sumber Penerangan Jalan Utama Desa. September 2015, https://www.bps. go.id/linkTabelStatis/view/id/1759, diakses pada 20 Juli 2017

Brockhaus, M., \& H. Kambiré, Decentralization: A window of opportunity for successful adaptation to climate change?" Adapting to Climate Change (2009): 399-416

Brondizio ES, Ostrom E, Young OR. Connectivity and the governance of multilevel social-ecological systems: the role of social capital. Annual Review of Environment and Resources ,34,1, (2009), hal. 253-278. DOI: 10.1146/annurev. environ.020708.10070 
Carol J. Pierce Colfer dan Doris Capistrano, eds, Politik Desentralisasi Hutan, Kekuasaan dan Rakyat Pengalaman di berbagai Negara, (Bogor: Center for InternationalForestry Research (CIFOR), 2006)

Colin MacAndrews, "Politics of the Environment in Indonesia", Asian Survey, Vol. 34, No. 4: 369 (1994), hal 373-380

Coopenergy, Rhine-Neckar Metropolitan Region-Promotion of the Covenant of Mayors, https:/ / goo.gl/KgorCy, diakses pada 20 Juli 2017

Coopenergy, SoutheastSweden -Sustainable Energy Community of 5 municipalities in Kalmar County, https:/ / goo.gl/GjwSNw, diakses pada 20 Juli 2017

Departemen Lingkungan Hidup Sumatera Utara, Pelaksanaan Inventarisasi Gas Rumah Kaca (GRK) di Provinsi Sumatera Utara, http://lcs-rnet.org, diakses pada 15 Mei 2017

E. Ampaire, L. Jassogne, H. Providence, M. Acosta, J. Twyman, L. Winowiecki, dan P. Asten, "Institutional challenges to climate change adaptation: A case study on policy action gaps in Uganda". Environmental Science \& Policy, Vol. 75: 81-90

Eyre, N. "Decentralization of governance in the low-carbon transition" di dalam Handbook on Energy and Climate Change, diedit oleh Roger Fouquet, 581-597. Edward Elgar, 2013

Federal Ministry for the Environment, Nature Conservation, Building and Nuclear Safety, Climate Action Plan 2050: Principles and goals of the German's government climate policy, https:/ / goo.gl/Br5ydC, diakses pada 15 Juli 2017

Fitzgibbon, J., dan Mensah, K. O. “Climate Change as a Wicked Problem”. SAGE Open, Vol.2, No. 2 (2012): 1-14

Grundmann, R. "Climate change as a wicked social problem". Nature Geoscience, Vol 9, No. 8 (2016): 562-563

Jakarta Post, Norway Slams Slow REDD+ Project Progress. Febuari 4, 2016. http:/ / www.thejakartapost.com/news/2016/02/04/norway-slams-slow-reddproject-progress.html, diakses 20 Mei 2017

Jänicke, M. "The Ambivalence of Environmental Governance" di dalam Environmental Governance in Europe, edited by Meuleman, L., Niestroy, I., Hey, Chr. RMNO: Den Haag, 2003

Jänicke, M., Schreurs, M., \& Töpfer, K, The Potential of Multi-Level Global Climate Governance, https:/ / goo.gl/XLiz8v, diakses 15 Mei 2017 
Johnson, C. A., Toly, N. J., \& Schroeder, H. (n.d.). The Urban climate challenge: Rethinking the role of cities in the global climate regime. London: Routledge

Jordan A, van Asselt H, Berkhout F, Huitema D, Rayner T. “Understanding the paradoxes of multilevel governing: climate change policy in the European Union". Global Environmental Politics 12(2), (2012), hal. 43-66. DOI:10.1162/ GLEP_a_00108.

Kern K, Bulkeley H. (2009). Cities, Europeanization and multi-level governance: governing climate change through transnational municipal networks. JCMS: Journal of Common Market Studies 47(2): 309-332. DOI:10.1111 /j.1468-5965.2009.00806. x.00806. x.

Kern, K. (2010.). Climate governance in the European Union multilevel system: The role of cities. Multilevel Environmental Governance, 111-130. doi: $10.4337 / 9780857939258.00016$

Kirsten Jörgensen, Anu Jogesh, dan Arabinda Mishra. "Multi-level climate governance and the role of the subnational level." Journal of Integrative Environmental Sciences no. 4, (2015)

Koski, C., \& Siulagi, A. (2016, 04). Environmental Harm or Natural Hazard? Problem Identification and Adaptation in U.S. Municipal Climate Action Plans. Review of Policy Research, 33(3), 270-290. doi:10.1111/ropr.12173

L. Hooghe dan G. Marks, “Types of Multi-Level Governance”, European Integration onlineOnline Papers (EIoP), Vol. 5, No. 11, (2011): 4-6

Larson, A. M., \&Soto, F. (2008, 11). Decentralization of Natural Resource Governance Regimes. Annual Review of Environment and Resources, 33(1), 213-239. DOI: 10.1146/annurev.environ.33.020607.095522

Levin, K., Cashore, B., Bernstein, S., \& Auld, G. (2009, 02). Playing it forward: Path dependency, progressive incrementalism, and the "Super Wicked" problem of global climate change. IOP Conference Series: Earth and Environmental Science, 6(50), doi:10.1088/1755-1307/6/0/502002

M. Jänicke, "The Multi-Level System of Global Climate Governance - the Model and Its Current Status", Environmental Policy and Governance, Vol. 27, (2017): hal 110-111

Marks, G. "Structural policy and multi-level governance in the EC". di dalam The State of the European Community vol. 2: The Maastricht Debates and Beyond, Cafruny AW, Rosenthal G (eds). Lynne Reiner: Boulder, CO, 2003 
Minang, Peter Akong, Meine Van Noordwijk, Lalisa A. Duguma, Dieudonne Alemagi, Trong Hoan Do, Florence Bernard, Putra Agung, et al. "REDD+ Readiness Progress Across Countries: Time for Reconsideration." Climate Policy 14, no. 6 (2014): 685-708.

Multilevel Constitutionalism for Multilevel Governance of Public Goods: Methodology Problems in International Law. Vol. 2017. Beaverton: Ringgold Inc, 2017

Naomi Klein, Climate change is a global emergency. Stop waiting for politicians to sound the alarm. September 20, 2014. https://www.theguardian.com/ commentisfree/2014/sep/20/climate-change-global-emergency-alarm, diakses 25 juli 2017

Naomi Klein, We're out of time on climate change. And Hillary Clinton helped get us here. April 7, 2016. https://www.theguardian.com/commentisfree/2016/ apr/07/out-of-time-climate-change-hillary-clinton, diakses 25 Juli 2017

Rabe, Barry. "Contested Federalism and American Climate Policy." Publius: The Journal of Federalism 41, no. 3. (Juni, 2011)Political Science Complete: 494-521. Salahuddin, M. The UNFCCC in the REDD: Compliance through transnational legal process in decentralised Indonesia: A thesis submitted for the degree of Doctor of Philosophy at the University of Otago, Dunedin, New Zealand, 2013

Scharpf, FW. "Introduction: the problem-solving capacity of multi-level governance". Journal of European Public Policy 4(4), (1997): 520-538. DOI:10.1080/135017697344046

Schreurs MA, Tiberghien Y. "Multi-level reinforcement: explaining European Union leadership in climate change mitigation". Global Environmental Politics, 7,4, (2007), hal: 19-46. DOI:10.1162/glep.2007.7.4.19

Sovacool, K. An International Comparison of Four Polycentric Approaches to Climate and Energy Governance, Energy Policy, Vol. 39 (6), (2011): 3832-3844. Steurer, Reinhard, and Clar, Christoph. "Is decentralisation always good for climate change mitigation? How federalism has complicated the greening of building policies in Austria". Policy Sciences, 48(1), (2014): 85-107. doi:10.1007/s11077014-9206-5

Sun, J., \& Yang, K. “The Wicked Problem of Climate Change: A New Approach Based on Social Mess and Fragmentation". Sustainability, 8(12), (2016): hal: 1-14. doi:10.3390/su8121312 
Weibust,I.Whatismultilevelenvironmentalgovernance?Whendoesitwork?Multilevel Environmental Governance, (n.d.): 249-270. doi:10.4337/9780857939258.00022

World Bank, Indonesia Climate Change Development Policy Project, http://projects. worldbank.org/P120313/indonesia-climate-change-development-policyproject?lang=en, diakses 30 Maret 201

Yang, Anastasia L., Mark D. A. Rounsevell, and Claire Haggett. "Multilevel Governance, Decentralization and Environmental Prioritization: How is it working in rural development policy in Scotland?" Environmental Policy \& Governance 25, Environment Complete, no. 6, (2015): 399-411. DOI:10.1002/ eet. 1690

Zeemering, E. S. What are the challenges of multilevel governance for urban sustainability? Evidence from Ottawa and Canada's national capital region. Canadian Public Administration, 59(2), (2016): 204-223. doi:10.1111/capa.12167 